\title{
Alterations of the LKB1 Gene in Lung Adenocarcinomas Induced by $\mathrm{N}$-Nitrosobis(2-Hydroxypropyl)amine in Rats
}

\author{
Masaki Tajiri ${ }^{a}$ Naoko Wakabayashia ${ }^{a}$ Megumu Tsujino ${ }^{a}$ Minako Fujii ${ }^{a}$ \\ Kyoko Okabe $^{\text {a }}$ Kanya Honoki $^{\text {b }}$ Toshifumi Tsujiuchia $^{\mathrm{a}}$ \\ a Laboratory of Cancer Biology and Bioinformatics, Department of Life Science, Faculty of Science and \\ Engineering, Kinki University, Higashiosaka, and ${ }^{\mathrm{b}}$ Department of Orthopedic Surgery, Nara Medical University, \\ Kashihara, Japan
}

\section{Key Words}

LKB1 $\cdot$ Lung adenocarcinoma $\cdot$ Nitrosamine

\begin{abstract}
Objective: Germ line mutations of the LKB1 gene cause the autosomal dominant Peutz-Jeghers syndrome (PJS), and PJS has also been associated with an increased risk of developing cancers, suggesting LKB1 may act as a tumor suppressor in PJS. By contrast, LKB1 mutations are rare events in most sporadic tumors in non-PJS patients, except for lung cancers. To better understand the involvement of LKB1 gene alterations during lung carcinogenesis, we investigated the LKB1 gene mutations and expressions in lung adenocarcinomas induced by $\mathrm{N}$-nitrosobis(2-hydroxypropyl)amine (BHP) in rats. Methods: Male Wistar rats, 6 weeks old, were given 2,000 ppm BHP in their drinking water for 12 weeks and maintained without further treatment until they were sacrificed at 25 weeks. A total of 15 lung adenocarcinomas were obtained, and genomic DNA was extracted for the search of mutations using polymerase chain reaction (PCR)-single strand conformation polymorphism analysis. To assess altered expressions of the LKB1 gene, reverse transcriptionPCR analysis was also performed. Results: No mutations were found throughout exons 1-9 in any of the tumors. Aberrant transcripts bearing deletions of nucleotides 216-1459,
\end{abstract}

289-1302, 268-1261, or 257-1378 were detected in 5 of 15 adenocarcinomas (33.3\%). Conclusion: These results suggest that alterations of the LKB1 gene might be involved in the development of lung adenocarcinomas induced by BHP in rats.

Copyright $\odot 2010$ S. Karger AG, Basel

\section{Introduction}

Lung cancer is one of the most common human malignancies, but the rate-limiting molecular events involved in its development remain largely unknown. The experimental model used in this study features the development of non-small cell lung cancers in rats given $\mathrm{N}$ nitrosobis(2-hydroxypropyl)amine (BHP) in their drinking water, with high yields of adenomatous lesions, including adenocarcinomas $[1,2]$. As the step-by-step development of lung malignancies is accessible with this model, the molecular mechanisms involved can be readily investigated. Taking advantage of this model, we have been able to accumulate data on genetic and epigenetic alterations during carcinogenesis, including Ki-ras and LPA1 gene mutations [3, 4], alterations in genes associated with transforming growth factor- $\beta$ signaling pathways $[5,6]$, and aberrant DNA methylation patterns of

\section{KARGER}

Fax +4161306 1234

E-Mail karger@karger.ch

www.karger.com (c) 2010 S. Karger AG, Basel

$1015-2008 / 10 / 0774-0225 \$ 26.00 / 0$

Accessible online at:

www.karger.com/pat
Toshifumi Tsujiuchi

Laboratory of Cancer Biology and Bioinformatics

Department of Life Science, Faculty of Science and Engineering

Kinki University, 3-4-1, Kowakae, Higashiosaka, Osaka 577-8502 (Japan)

Tel. +81 66772 2332, Fax +81 66723 2721, E-Mail ttujiuch@life.kindai.ac.jp 
E-cadherin, p16 and Tslc1 genes associated with reduced expressions $[7,8]$.

The LKB1 protein has serine-threonine kinase activity and possesses a nuclear localization signal in the N-terminal noncatalytic region (residues 38-43) and a kinase domain (residues 49-308) [9]. LKB1 indicates several biological functions, including regulation of cell polarity, p53-mediated apoptosis and cell proliferation [9, 10]. Germ line mutations of the LKB1 gene cause the autosomal dominant Peutz-Jeghers syndrome (PJS) characterized by gastrointestinal hamartomatous polyposis and melanin pigmentation [11-13]. PJS has also been associated with an increased risk of developing cancer, including gastrointestinal, lung, liver, breast and pancreatic cancers, suggesting that LKB1 may act as a tumor suppressor in PJS [13-15]. Although LKB1 mutations have also been detected in a variety of sporadic tumors, their frequency is low [16]. By contrast, a highly frequent alteration of the LKB1 gene in lung tumors has been reported [17-19].

In the present study, to assess an involvement of the LKB1 gene in the development of rat lung tumors, we investigated the LKB1 gene mutation and its expression pattern in rat lung adenocarcinomas induced by BHP.

\section{Materials and Methods}

\section{Animals and Treatment}

A total of 18 male Wistar rats, aged 5 weeks, were purchased from Japan SLC, Inc. (Shizuoka, Japan) and housed 3-5 per cage in an air-conditioned room with a constant temperature of $25^{\circ} \mathrm{C}$ and a 12-hour light-dark cycle. Food and water were provided ad libitum throughout the study. After a 1-week acclimation period on a basal diet in pellet form (CF-2 Diet; Clea Japan, Tokyo, Japan), 15 animals received drinking water containing BHP (Nakalai Tesque Co. Ltd., Kyoto, Japan) at a concentration of 2,000 ppm for 12 weeks, and drinking water without BHP thereafter. In order to obtain normal lung tissue, 3 animals were maintained free from carcinogen exposure throughout the experimental period $[1,2]$.

\section{Tissue Preparation}

All rats were exsanguinated from the abdominal aorta under light ether anesthesia 25 weeks after the beginning of the experiment. The lungs were immediately excised, and grossly apparent tumors were dissected from their surrounding tissue. Samples were frozen in liquid nitrogen and stored at $-80^{\circ} \mathrm{C}$ until analysis. Portions of the tumors were fixed in $10 \%$ neutrally buffered formalin at $4^{\circ} \mathrm{C}$, routinely processed for hematoxylin and eosin staining, and histopathologically evaluated according to diagnostic criteria previously described [1-3]. All experiments and procedures carried out on the animals were approved by the Animal Care Committees of Kinki University and Nara Medical University.
Polymerase Chain Reaction-Single Strand Conformation Polymorphism Analysis

Genomic DNA was extracted from the frozen tissues of 15 adenocarcinomas and 3 normal lung tissues as described previously $[7,8]$. Polymerase chain reaction (PCR)-single strand conformation polymorphism (SSCP) analysis was conducted to look for mutations in the LKB1 gene. The primers used in this study were designed to amplify exons 1-9 of the LKB1 gene with intron sequences flanking coding exons (NCBI accession No. NC_005106) (table 1). Briefly, PCR for SSCP analysis was performed in $10 \mu \mathrm{l}$ of reaction mixture containing $1 \mu \mathrm{M}$ of each primer, $200 \mu \mathrm{M}$ of each dNTP, $1 \times$ PCR buffer (Applied Biosystems Japan Ltd., Tokyo, Japan), 2.5 units of AmpliTaq (Applied Biosystems Japan) and 0.5 $\mu$ l of extracted genomic DNA under the following reaction conditions: primary denaturation for $2 \mathrm{~min}$ at $96^{\circ} \mathrm{C}$ followed by 36 cycles of $15 \mathrm{~s}$ of denaturation at $96^{\circ} \mathrm{C}, 15 \mathrm{~s}$ of annealing at $56-$ $66^{\circ} \mathrm{C}$ and $1 \mathrm{~min}$ of extension at $72^{\circ} \mathrm{C}$, and a final extension period of $5 \mathrm{~min}$ at $72^{\circ} \mathrm{C}$. PCR products were diluted with $10 \mu \mathrm{l}$ of loading solution containing $90 \%$ formamide, $20 \mathrm{~mm}$ EDTA, $0.05 \%$ xylene cyanol and $0.05 \%$ bromophenol blue. Aliquots containing $6 \mu \mathrm{l}$ of diluted products were electrophoresed on polyacrylamide gels using a GeneGel Excel 12.5/24 Kit (GE Healthcare UK Ltd., Little Chalfant, UK) at $8,15,18$ and $20^{\circ} \mathrm{C}$ for $90 \mathrm{~min}$ at $15 \mathrm{~W}$, using a GenePhor Electrophoresis Unit (GE Healthcare UK). After electrophoresis, the gels were stained with a DNA Silver Staining Kit (GE Healthcare UK) [4].

\section{Reverse Transcription-PCR Amplification of Aberrant}

Transcripts of the LKB1 Gene

Total RNA was extracted from frozen tissue using ISOGEN (Nippon Gene, Inc., Toyama, Japan) and first-strand cDNA was synthesized from $0.5-\mu$ g samples with a Transcriptor First Strand cDNA Synthesis Kit (Roche Diagnostics Co. Ltd., Mannheim, Germany). To eliminate possible false-positives caused by residual genomic DNA, all samples were treated with DNase.

The cDNAs synthesized from 15 adenocarcinomas and 3 normal lung tissues were assessed for aberrant splicing of the LKB1 gene by nested reverse transcription (RT)-PCR analysis using the primers $1 \mathrm{~F}$ ( $5^{\prime}$-CGGGTGGGGGAAATTTGAAC-3'), 1R (5'CAGACAGGCCCGGAATCAGT-3'), 2F (5'-AAGAATTGGCGCTCCCGAAG-3') and 2R (5'-GGACACCTGCCCAAAGATCC$\left.3^{\prime}\right)$ designed according to the rat LKB1 cDNA sequence (NCBI accession No.XM_234900). The first round of PCR amplification was performed in $10 \mu \mathrm{l}$ of reaction mixture consisting of $1 \mu \mathrm{M}$ of $1 \mathrm{~F}$ and 1R, $200 \mu \mathrm{M}$ of each dNTP, $1 \times$ PCR buffer (Applied Biosystems Japan), 2.5 units of AmpliTaq (Applied Biosystems Japan) and $0.5 \mu \mathrm{l}$ of synthesized cDNA under the following reaction conditions: primary denaturation for $2 \mathrm{~min}$ at $96^{\circ} \mathrm{C}$ followed by 36 cycles of $15 \mathrm{~s}$ of denaturation at $96^{\circ} \mathrm{C}, 15 \mathrm{~s}$ of annealing at $62^{\circ} \mathrm{C}$ and $1 \mathrm{~min}$ of extension at $72^{\circ} \mathrm{C}$, and a final extension period of $5 \mathrm{~min}$ at $72^{\circ} \mathrm{C}$. The amplified product was diluted 20 -fold in TE buffer, and $0.5 \mu \mathrm{l}$ of the dilutant was subjected to the second round of PCR amplification under the above-mentioned conditions, using primers $2 \mathrm{~F}$ and $2 \mathrm{R}$. The PCR products were then separated on $2 \%$ NuSieve agarose gels (BMA, Rockland, Me., USA) containing $0.05 \mu \mathrm{g} / \mathrm{ml}$ ethidium bromide. Each nested RT-PCR assay was repeated at least twice for confirmation using the originally extracted RNA. 
Table 1. Primers used for PCR-SSCP analysis

\begin{tabular}{|c|c|c|c|}
\hline Location & Primer & Product size, bp & $\begin{array}{l}\text { Annealing } \\
\text { temperature, }{ }^{\circ} \mathrm{C}\end{array}$ \\
\hline Exon 1 & $\begin{array}{l}\text { F: 5'-GACAAAGAGTGGGCCAGGAT-3' } \\
\text { R: 5'-CTCCTTCTTGACGTTGGCCT-3' }\end{array}$ & 322 & 65 \\
\hline Exon 2 & $\begin{array}{l}\text { F: 5'-AAACAAGCTCAACTCCCACC-3' } \\
\text { R: 5'-CCATCCCACAGGATATATCT-3' }\end{array}$ & 221 & 57 \\
\hline Exon 3 & $\begin{array}{l}\text { F: 5'-TTATAGGCATGTGGCAGTGG-3' } \\
\text { R: 5'-ACTCACCCATGAGCTTGGCA-3' }\end{array}$ & 287 & 63 \\
\hline Exons 4 and 5 & $\begin{array}{l}\text { F: 5'-GTCCCACCCATTCAGGTA-3' } \\
\text { R: 5'-ACATACAAGACACTCACAGTG-3' }\end{array}$ & 369 & 54 \\
\hline Exon 6 & $\begin{array}{l}\text { F: 5'-ATGTGTCCACTCTGGGAGTT-3' } \\
\text { R: 5'-TGATTAGAGATGCCCACCTC-3' }\end{array}$ & 226 & 61 \\
\hline Exon 7 & $\begin{array}{l}\text { F: 5'-GGGTGGGAGGTTTCTAAGAT-3' } \\
\text { R: 5'-CACTCACCTGTGCTGTCTAA-3' }\end{array}$ & 263 & 59 \\
\hline Exon 8 & $\begin{array}{l}\text { F: 5'-TGCAGCTGGTTCCGGAAGAAA-3' } \\
\text { R: 5'-CAACTCACCAGGCACTGTGA-3' }\end{array}$ & 210 & 65 \\
\hline Exon 9 & $\begin{array}{l}\text { F: 5'-GCTTGCCATCTTCCCGCAGG-3' } \\
\text { R: 5'-CGCCCACTGTGAACACCAAA-3' }\end{array}$ & 275 & 65 \\
\hline
\end{tabular}

DNA Nucleotide Sequencing

Following the RT-PCR analysis, DNA fragments from aberrant splicing bands in the gels were extracted and reamplified. The obtained PCR products were also directly sequenced using a BigDye Terminator v3.0 Cycle Sequencing Ready Reaction Kit (Applied Biosystems Japan) and an ABI PRISM 310 Genetic Analyzer (Applied Biosystems Japan). To confirm the results, PCR amplification was repeated on the same samples and each PCR product was sequenced with forward and reverse primers at least twice.

\section{Results and Discussion}

The incidence of lung adenocarcinomas induced by BHP was approximately $33 \%$ [1-3]. Multiple adenomatous lesions including alveolar hyperplasias, adenomas and adenocarcinomas were induced in rats given BHP [1-3]. In this study, a total of 15 adenocarcinomas induced by BHP in 15 rats were used for the analysis. Histologically, these adenocarcinomas were poorly circumscribed and composed of well or moderately differentiated cancer cells in papillary or tubular patterns with interstitial connective tissues. These appearances were quite similar to human alveolar/bronchiolar adenocarcinomas $[1,2]$. Three normal lung tissues, obtained from untreated rats, were used as controls to eliminate the possibility of contamination with microscopically undetected cancerous lesions.

In several human cancers, somatic mutations of the LKB1 gene have been reported [16]. However, it has been demonstrated that LKB mutations are rare events in most sporadic tumor types [16]. By contrast, highly frequent alterations of LKB1 were detected in lung cancers and their cell lines [17-19]. The LKB1 gene inactivation occurred in half of lung adenocarcinoma cell lines and one third of primary lung adenocarcinomas $[17,18]$. In other literature, the alterations were found in 21 out of 70 cancer cell lines (30\%) and were more frequently detected in non-small cell lung cancers (39\%) than in small cell lung cancers (5\%) [19]. In primary lung adenocarcinomas, LKB1 mutations were found in $13 \%$ of pathological stage I-II cases and $12 \%$ of brain metastases [19]. In the present study, we thus conducted PCR-SSCP analysis to seek LKB1 gene mutations in rat lung adenocarcinomas induced by BHP. However, no mutations were detected throughout exons 1-9 in 15 adenocarcinomas. Also, no homozygous deletions were found in them (data not shown). We confirmed by direct sequencing analysis that all PCR products contained the normal LKB1 sequence. This suggests that the LKB1 gene mutation is not induced 
Fig. 1. Aberrant transcription of the LKB1 gene. a Representative results of nested RT-PCR analysis. $\mathrm{M}=$ Size marker; $\mathrm{N}=$ normal lung tissue. b Patterns of aberrant transcripts detected by DNA sequencing analysis. The arrows indicate the junctions between nt 215 and 1460 (AC3), 288 and 1303 (AC6), and 267 and 1262 (AC9) in the aberrant transcripts. AC $=$ Adenocarcinoma.

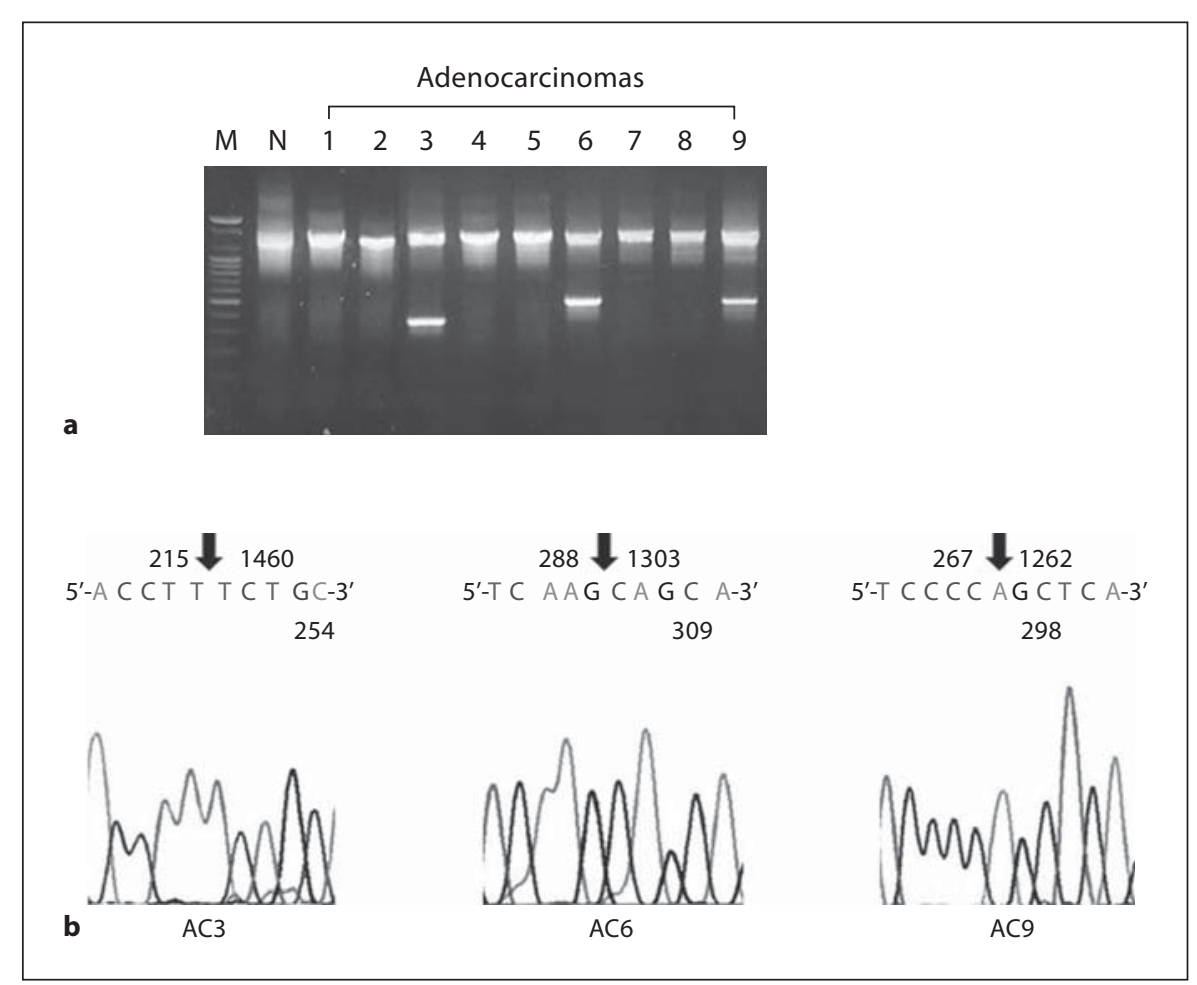

by BHP per se. The discrepancy in the mutation frequency between human and rat cases may be due to the difference of species or carcinogenic factors.

Altered expressions of the LKB1 gene have also been reported in lung cancer cell lines [19]. In 70 lung cancer cell lines, shorter-sized RT-PCR products were found in 8 cell lines (11\%), and 9 cell lines (13\%) showed the absence of the products which implied no or decreased expression of LKB1 mRNA [19]. Therefore, to assess altered expressions of the LKB1 gene, we performed RT-PCR analysis. Representative results of nested RT-PCR and DNA sequencing analyses are shown in figure 1. The RTPCR analysis revealed that, although only the normalsized product band was amplified at 1,597 bp in all 3 normal lung tissues, an additional abnormal-sized product was evident in 5 out of 15 adenocarcinomas (33.3\% incidence). Such abnormal-sized transcripts were seen at 4 different positions: 353, 475, 583 and $603 \mathrm{bp}$. Sequencing analysis revealed that these aberrant fragments were due to deletions in the regions of nucleotides (nt) 216-1459, 257-1378, 289-1302 and 268-1261 (table 2). Neither loss of the LKB1 gene nor reduced expressions of it were detected (data not shown). These deleted regions include a catalytic kinase domain of the LKB1 protein (nt 111-942) and a regulatory domain (nt 945-1301) which contains
Table 2. Results for alterations of the LKB1 gene in lung adenocarcinomas induced by $\mathrm{BHP}$ in rats

\begin{tabular}{ll}
\hline Adenocarcinomas & cDNA alteration $(4 / 12 ; 33.3 \%$ incidence) \\
\hline 3 & 1,244 bp deletion (nt 216-1459) \\
6 & 1,014 bp deletion (nt 289-1302) \\
9 & 994 bp deletion (nt 268-1261) \\
12 & 1,122 bp deletion (nt 257-1378) \\
\hline
\end{tabular}

a conserved phosphorylation consensus sequence for cAMP-dependent protein kinase close to its carboxyl-terminal end [13]. Therefore, these results suggest that the dysfunction of the LKB1 gene due to aberrant transcriptions may be involved in the development of rat lung adenocarcinomas induced by BHP.

In human lung cancer cell lines, no or abnormal-sized mRNA expressions were due to homozygous deletions in the region of exon 1 and/or a $0.5-\mathrm{kb}$ upstream, or intragenic homozygous deletions $[18,19]$. In contrast with cell lines, no large deletions of the LKB1 gene were detected in tumor specimens of lung cancers, suggesting that the contamination of noncancerous cells in the tumor specimens masked large deletions [19]. In the present study, 
homozygous deletions were not found in PCR-SSCP analysis, and all abnormal-sized bands were displayed with the wild type of the LKB1 in RT-PCR analysis. Therefore, it is possible that the normal-sized bands may be due to the contamination of normal cells in tumor samples. To clarify the involvement of homozygous deletion in abnormal-sized mRNA expressions in rat tumors as well as human cases, it is necessary to perform RT-PCR analysis with rat tumor cell lines.

In conclusion, the present investigation of alterations of the LKB1 gene in lung adenocarcinomas induced by $\mathrm{BHP}$ in rats indicated aberrant transcripts due to deletion in $33.3 \%$ of cases, but no mutations. Recently, we have reported the LKB1 mutations in pancreatic duct adenocarcinomas induced by nitroso compounds in hamsters [20].
To clarify whether the LKB1 gene mutations may be dependent on chemical carcinogens or species, we are currently investigating the LKB1 mutations in mouse lung tumors induced by other chemical carcinogens.

\section{Acknowledgements}

This study was supported in part by the Foundation for Promotion of Cancer Research in Japan, a Grant-in-Aid (20591765) for Scientific Research from the Ministry of Education, Culture, Sports, Science and Technology of Japan, a grant (21321201) from the Ministry of Health, Labor and Welfare of Japan and a grant (RK-027) from the Faculty of Science and Engineering of Kinki University.

\section{References}

1 Konishi Y, Denda A, Kondo H, Takahashi S: Lung carcinomas induced by oral administration of N-bis(2-hydroxypropyl)nitrosamine in rats. Jpn J Cancer Res 1976;67:773780 .

2 Konishi Y, Kondo H, Denda A, Takahashi S, Inui S: Lung carcinomas induced by oral administration of N-bis (2-hydroxypropyl)nitrosamine in rats; in: Severi I (ed): Tumors of Early Life in Man and Animals. Perugia Quadrennial International Conference of Cancer, Perugia University, Perugia, 1978, pp 637-649.

-3 Kitada H, Tsutsumi M, Tsujiuchi T, Takahama M, Fukuda T, Narita N, Konsihi Y: Frequent mutations of Ki-ras but no mutations of Ha-ras and p53 in lung lesions induced by $\mathrm{N}$-nitrosobis(2-hydroxypropyl)amine in rats. Mol Carcinog 1996;15:276-283.

-4 Yamada T, Furukawa M, Hotta M, Yamasaki A, Honoki K, Fukushima N, Tsujiuchi T: Mutations of lysophosphatidic acid receptor-1 gene during progression of lung tumors in rats. Biochem Biophys Res Commun 2009; 378:424-427.

5 Tsujiuchi T, Sasaki Y, Tsustumi M, Konishi Y: Mutations and reduced expression of the transforming growth factor- $\beta$ receptor II gene in rat lung adenocarcinomas induced by $\mathrm{N}$-nitrosobis(2-hydroxypropyl)amine. Jpn J Cancer Res 2000;91:1090-1095.
6 Tsujiuchi T, Sasaki Y, Tsustumi M, Konishi Y: Mutations of the smad 2 and $\operatorname{smad} 4$ genes in lung adenocarcinomas induced by $\mathrm{N}$ nitrosobis(2-hydroxypropyl)amine in rats. Mol Carcinog 2000;29:87-91.

$\checkmark 7$ Kato A, Shimizu K, Shimoichi Y, Fujii H, Honoki K, Tsujiuchi T: Aberrant DNA methylation of E-cadherin and p16 genes in rat lung adenocarcinomas induced by $\mathrm{N}$-nitrosobis (2-hydroxypropyl)amine. Mol Carcinog 2006; 45:106-111.

-8 Shimizu K, Itsuzaki Y, Onishi M, Fujii H, Honoki K, Tsujiuchi T: Reduced expression of the Tslcl gene and its aberrant DNA methylation in rat lung tumors. Biochem Biophys Res Commun 2006;347:358-362.

-9 Alessi DR, Sakamoto K, Bayascas JR: LKB1dependent signaling pathways. Annu Rev Biochem 2006;25:137-163.

10 Bass AF, Smit L, Clevers H: LKB1 tumor suppressor protein: PARtaker in cell polarity. Trends Cell Biol 2004;14:312-319.

11 Jeghers H, McKusick VA, Katz KH: Generalized intestinal polyposis and melanin spots of the oral mucosa, lips and digits. N Engl J Med 1949;241:1031-1036.

12 Hemminki A, Markie D, Tomlinson I, et al: A serine/threonine kinase gene defective in Peutz-Jeghers syndrome. Nature 1998;391: 184-187.

13 Jenne DE, Reimann H, Nezu J, et al: PeutzJeghers syndrome is caused by mutations in a novel serine threonine kinase. Nat Genet 1998;18:38-43.
14 Giardiello FM, Welsh SB, Hamilton SR, et al: Increased risk of cancer in the Peutz-Jeghers syndrome. N Engl J Med 1987;316:15111514.

15 Hemminki A: The molecular basis and clinical aspects of Peutz-Jeghers syndrome. Cell Mol Life Sci 1999;55:735-750

16 Sanchez-Cespedes M: A role for LKB1 gene in human cancer beyond the Peutz-Jeghers syndrome. Oncogene 2007;26:7825-7832.

17 Sanchez-Cespedes M, Parrella P, Esteller M, Nomoto S, Trink B, Engles JM, Westra WH, Herman JG, Sidransky D: Inactivation of LKB1/STK11 is a common event in adenocarcinomas of the lung. Cancer Res 2002;62: 3659-3662.

18 Carretero J, Medina PP, Pio R, Montuenga LM, Sanchez-Cespedes M: Novel and natural knockout lung cancer cell lines for the LKB1/STK11 tumor suppressor gene. Oncogene 2004;23:4037-4040.

19 Matsumoto S, Iwakawa R, Takahashi K, Kohno T, Nakanishi Y, Matsuno Y, Suzuki K, Nakamoto M, Shimizu E, Minna JD, Yokota J: Prevalence and specificity of LKB1 genetic alterations in lung cancers. Oncogene 2007; 26:5911-5918.

20 Furukawa M, Yamasaki A, Yoshida J, Tsujino M, Wakabayashi N, Honoki K, Tsujiuchi T: Mutations of LKB1 gene in pancreatic ductal adenocarcinomas induced by $\mathrm{N}$ nitrosobis(2-oxoprpyl)amine in hamsters. Anticancer Res 2009;29:4047-4050. 